\title{
Factors influencing service quality in restaurant business: A case of SME Bank Cafeteria
}

\author{
Siti Zakiah Abu Bakar ${ }^{* 1}$, Choo Chun Hoong ${ }^{1}$
}

\author{
${ }^{I}$ School of Technology Management and Logistics Universiti Utara Malaysia \\ *Corresponding author e-mail: ctzakiah@uum.edu.my
}

\begin{abstract}
Many restaurant businesses have faced demise due to stiff competition. Competition is more aggressive due to the emerging of on-line food services and the changing food preferences among consumers. Due to the increasing competition, 'survival of the fittest' will be those who could understand the factors that may influence customers' satisfaction. Therefore, this study explores what is deemed important by customers in restaurant service. Restaurant service quality are food quality, price, and physical environment. To conduct the research, a survey in the form of online questionnaire was distributed to the resident in hostel SME Bank. A total of 100 respondents which from both genders and from different races participated in this study. The key dimensions of food quality, price, physical environment, and customer satisfaction were identified through literature. From the result of the data, it shows that the food quality is the most important factor which impacts on customer's satisfactions. However, the physical environment is not significant variable of customers satisfaction. Cafeteria owner of SME Bank Cafeteria should pay more attention on food quality and price adjustment to improve the customer satisfaction. Findings from this research provide a useful suggestion in the area of customer satisfaction with the specific interest in restaurant business.
\end{abstract}

Keywords—service quality, customer satisfaction, food quality, price, physical environment

\section{INTRODUCTION}

Restaurant service providers are facing stiff competition to maintain in the business. To maintain competition, service providers must be able to satisfy their customers and limit errors in service delivery. According to [1] many service delivery errors and problems can occur and that is not beneficial for the reputation of the organization. The problem with service failure is that it may lead to a destroyed relationship between the customer and the organization.

This is the case in Universiti Utara Malaysia (UUM) as there are more than 20 restaurants serving the same university community. University community include all staff and students working or studying in UUM. Many restaurant owners in UUM fail to prolong their business due to poor sales. The challenges are enhanced due to the existence of food deliveries selling varieties of hip food within campus. New hip or trendy food are popular especially among students. The number of service providers increased as now both the university cafeteria and online food providers are serving the same population. Hence, it is difficult to achieve competitive advantages and increase sales. The service providers or restaurant owners have to compete among one another as well as with the external food providers to capture the finite university market. Not many non-university communities will venture to UUM for their meals as only the fittest will survived. The provider who could satisfy the most customer will stay in business.

Therefore, customer satisfaction is important as it is a key factor to achieve competitive advantage. Reference [2] demonstrated that, customer satisfaction will create loyal and regular customer which will provide benefits for the restaurant.

The restaurant under study is known as SME Bank Cafeteria, which is located at the students housing in Bukit Kachi, UUM. This study focuses on factors that are important to improve restaurant service quality in a university setting. From past literature, it was observed that food quality, price, and physical environment are the important predictors to customer satisfaction [3] in restaurant business. The main objective of this research is to investigate the relationship between service quality and customer satisfaction. To achieve this objective, the researcher used service quality dimensions (food quality, price and physical environment) as independent variables and customer satisfaction as dependent variable.

\section{LITERATURE REVIEW}

\section{A. Service Quality Dimensions}

Past research depicts many dimensions of service quality and their relationship with customer satisfaction. Some examples of service quality dimensions is responsiveness, food quality, physical design and price [4], food quality, service quality, price and value, atmosphere and convenience [5], physical environment, service, food, price [3], price fairness, food quality, and physical environment [6]. Similarly, this study investigates the relationship between food quality, physical environment and price as service quality dimension and their relationship with customer satisfaction.

\section{B. Customer Satisfaction \\ Customer satisfaction is the customers overall}


feeling of contentment with a customer interaction. Customer satisfaction in services has been defined as the degree to which service performance meets or exceeds the customer's expectations [7]

Customer satisfaction is an important as it is linked to purchase loyalty. It is a feeling that customers have as a result of the post-consumption evaluation of services. Customer satisfaction can influence customers' trust [3] and has been recognized as one of the most important determinants of customer loyalty [8].

In the restaurant context, satisfied customers are found to be more loyal as opposed to unsatisfied customers. Therefore, customers who are satisfied with the services are more likely to patron frequently and are more willing to spread a positive word of-mouth and recommend the service to others. Customer satisfaction become the most significant aspect in the area of business, because satisfied customers will bring significant impact on the profits of business. Customer satisfaction can be used to predict repeat patronage leading to brand loyalty and new consumers [9].

\section{Food Quality}

Food quality plays a pivotal role in the restaurant experience as it is the core product of a restaurant. Past study

[10] express that quality plays a vital role in formative and influencing customer satisfaction. In definition, food quality refers to standard of food that are acceptable for customers. It is widely believed that food quality is a key factor influencing customer loyalty and after-dining expectations. When consumers tend to decide to visit a restaurant, they are likely to consider food quality, as it plays a key role in reflecting the restaurant's core attributes [11]. Other studies found a linked between food attributes such as food taste, food freshness, food temperature and food presentation were and customers' satisfaction [12] and it is reported that food quality has been considered as an essential aspect of any restaurant to success. Past studies have shown that food quality directly effect on customer satisfaction [13] [14].

\section{Price}

Price is an explanatory variable designed to influence consumer satisfaction, as customers often reflect on prices when they estimate the price of a product or service they receive [15]. The reasonableness of the price has a significant impact on the customer's purchase decision.

Price has been widely accepted as an essential marketing factor influencing customer satisfaction. Customers perceived the value of the service received must be equal to the price. Pricing for a product or service is not easy to decide because the core values of the available goods are used to evaluate price that are crucial to customer satisfaction because the price is the significant factor in helping customer to estimate the value of good or service [16]. Price identification can improve a company's profitability and customer satisfaction and escalating the observation that a price is levelheaded is link with customer maintenance and business success [17].

The price of the item on the menu will also have an incredible impact on the customer because the price can be a drawing or repulsing factor [18]. Price plays a major role for the students when they choose a restaurant because they have limited finances. Cost is the main factor in university food service operations as students prefer to patron restaurant or cafeteria with lower price [19]. According to [20], one of the most imperative critical variables that urge students to return to a food service operation the right value for money which contribute to students' satisfaction.

\section{E. Physical Environment}

The physical environment is referred to the physical environment in which the service delivery process takes place that influenced customers' perceptions of service quality [21]. Physical environment is another aspect in which a restaurant can build its competitive advantage. Physical environment consists of all the tangible and intangible elements that exist inside and outside a restaurant. The tangible elements are such as chair, table while intangible characteristics include of temperature, noise, lighting and quality of air. According to [12], in dining restaurants, element that can be added to the environment are set up all the interior outline, style theme, charming music, lighting as well as format and shadow.

The restaurant environment may be one of the successful factors in building a stronger brand image which directly increased customer loyalty by the service experience. In a restaurant, a well-maintained physical environment should provide a distinctive experience for customer to attract them to frequently visit the restaurant. In addition, the importance of the physical environment to create an image and influence customer satisfaction is particularly relevant [13].

\section{F. Theoretical Framework and Hypotheses}

From the literature, the researcher develops a theoretical framework which was investigated in this study (Fig.1) Similarly, three hypotheses were formulated.

H1: There is a significant relationship between food quality and customer satisfaction in SME Bank Cafeteria.

$\mathrm{H} 2$ : There is a significant relationship between physical environment and customer satisfaction in SME Bank Cafeteria.

H3: There is a significant relationship between price and customer satisfaction in SME Bank Cafeteria.

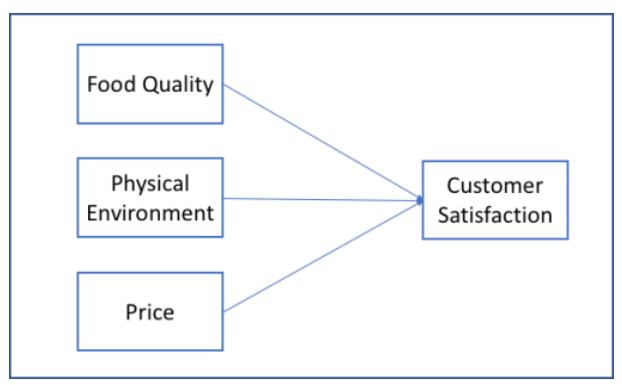

Fig 1 Theoretical Framework 


\section{METHODS}

In this research, data was collected among students who patron the SME Bank Cafeteria. The relevant sample size are 100 students that have meals in SME Bank Cafeteria. These respondents were asked to answer the online questionnaire about service quality provided by the cafeteria.

Likert-liked scale ranging from 1 to 5 were used, where number 1 indicates strongly disagree with the statement, number 2 means disagree with the statement, number 3 indicates neutral, number 4 indicates agree with the statement and number 5 indicates strongly agree with the statement.

The questionnaire used in this research was adapted from previous research. The service quality dimension food quality contains 6 items, price contains 4 items and physical environment contains 5 items were adapted from [6]. For the dependent variable, customer satisfaction contains 4 items which was adapted from [4].

In order to address the research objective and to fulfill the hypothesis formulated, data collected from the questionnaire was analyzed using IBM SPSS version 25. The mean, median and mode were used to measure the level of customer satisfaction. Regression analysis was employed to determine the relationship between service quality and customer satisfaction.

\section{RESULTS}

\section{A. Demographics}

A total of 100 respondents participated in the survey where $28 \%$ were male respondents and $72 \%$ female. Majority of respondents are of Malay, which constitute of $52 \%$ of our total respondents. This is followed by Chinese $36 \%$ and Indian 11\%. Meanwhile the remaining $1 \%$ respondents is from other races.

As for the age group, $31 \%$ of the respondents are in the group of 19-20 years old, $29 \%$ respondents are in the group of 21-22 years old. 23-24 years old is the highest in age group which is $34 \%$ while the remaining $6 \%$ respondents are in the group of above 24 years old.

In term of year of study, Year 1 and year 2 students have each contributed $24 \%$ of respondents, $22 \%$ of the respondents are currently in their third year of study followed by $30 \%$ of the respondents are in their fourth year.

For this study, researcher have targeted all respondents from College of Business (COB), College of Arts and Sciences (CAS) and College of Law, Government and International Studies (COLGIS). 59\% of respondents come from $\mathrm{COB}, 23 \%$ of respondents from CAS and $18 \%$ of respondents from COLGIS.

For frequency of visit to the cafeteria, $22 \%$ of the respondents visit SME Bank Cafeteria 0-1 times per week. 2- 3 times per week is the highest frequency which is $47 \%$ of respondents, $21 \%$ of respondents visit $4-5$ times per week while $10 \%$ of respondents visit 6-7 times per week.

\section{B. Reliability Tests}

All the variables under study have Cronbach alpha value of greater than 0.7 and 0.9 . The general rule of thumb is that a Cronbach's alpha of 0.70 and above is good, 0.80 and above is better, and 0.90 and above is best. Hence, the results show good and better support for internal consistency. Refer to table 1.

TABLE 1. RELIABILITY TEST

\begin{tabular}{|l|c|c|}
\hline \multicolumn{1}{|c|}{ Variable } & Items & $\begin{array}{c}\text { Cronbach's } \\
\text { Alpha }\end{array}$ \\
\hline Food Quality & 6 & 0.877 \\
\hline Price & 4 & 0.808 \\
\hline $\begin{array}{l}\text { Physical } \\
\text { Environment }\end{array}$ & 5 & 0.795 \\
\hline $\begin{array}{l}\text { Customer } \\
\text { Satisfaction }\end{array}$ & 4 & 0.902 \\
\hline
\end{tabular}

\section{Regression Model Summary}

The regression model summarized in Table 2 shows the values of $R$ and $R 2$. The value of $R$ which indicates simple correlation between dependent and all independent variables is $0.817(\mathrm{R}=0.817)$. This indicates high degree of correlation between the variables.

The coefficient of determination, $\mathrm{r} 2$, is 0.667 . We can say that $66.7 \%$ of the variation in customer satisfaction is significantly explained by the variation in three independent variables (food quality, price, physical environment).

TABLE 2. REGRESSION MODEL

\begin{tabular}{|l|l|l|l|l|}
\hline Model & R & R Square & Adjusted R Square & $\begin{array}{l}\text { Std. Error of } \\
\text { the Estimate }\end{array}$ \\
\hline 1 & $.817 \mathrm{a}$ & .667 & .657 & .56158 \\
\hline
\end{tabular}

\section{Hypothesis Testing}

The Coefficients table (refer to Table 3 in Appendix) helps to indicate the effect of independent variables on the dependent variable. Based on the table above, customer satisfaction is primarily predicted by food quality and price. Prediction values as shown on Table 4.5.2, $\mathrm{B}=0.7$, Beta $=0.592, \mathrm{t}=7.350$, and $\mathrm{p}<0.05$ for food quality, $\mathrm{B}=0.277$, Beta $=0.226, \mathrm{t}=3.174, \mathrm{p}<0.05$ for price.

Hence, food quality and price have a significant relationship towards customer satisfaction. Therefore, $\mathrm{H} 1$ and $\mathrm{H} 2$ is supported. Physical environment is insignificant which $\mathrm{B}=0.153$, and Beta $=0.115, \mathrm{p}=$ 0.137 . Physical environment is not significant predictors of customers' satisfaction in this model. Thus, H3 is not supported.

\section{DISCUSSION}

There are three dimensions under service quality that have been studied and examined by the researcher in order to complete the research project. The three 
dimensions are food quality, price, and physical environment. Researcher have examined the relationship of each dimension towards customer satisfaction. Based on Pearson's correlation, it shows the three variables have the Pearson correlation coefficient value of $0.785,0.600$ and $0.585, p<0.05$, indicate that all the three dimensions have positive relationship on customer satisfaction. By referring to the past research, it is stated that food quality, price and physical environment is significant predictor on customer satisfaction [6]. Based on the result of multiple regression, it shows that food quality and price have significant relationship on customer satisfaction because the p-value is less than 0.05. Therefore, there is a significant relationship between food quality and price with customer satisfaction which has been supported by past research. These two variables are consistent with the past researchers. However, this research show there is no significant relationship between physical environment with customer satisfaction. Hence, the findings are not consistent with the past research.

The results of this study specifically show that food quality has a great influence on customer satisfaction in SME Bank Cafeteria. Food quality is significant predictors of customers satisfaction and has a positive and strong relationship with customer satisfaction. It is one of the most important factors resulting in higher levels of customer satisfaction. Hence, our findings are consistent with the pass researchers [14][6].

\section{CONCLUSION}

The main objective of this research is to investigate the relationship between service quality and customer satisfaction. To achieve this objective, the researcher used service quality dimensions (food quality, price and physical environment) as independent variables and customer satisfaction as dependent variable. The combination of independent variable and the relationship of service quality on customer satisfaction has been examined. This study can give the indicator on which factors affected and can be used to predict the customer satisfaction among student.

Customer satisfaction is a dimension that measures the products and services provided by the business firm to meet the customer's anticipation and this has been acknowledged as a key performance pointer for business organization. Therefore, customer satisfaction is the soul of every business and the capacity to make customers satisfy is a key for several reasons. This has brought about a paradigm shift in research of finding determinants factors that influencing customer's satisfaction in a restaurant, therefore it is very vital for a marketer and restaurateurs to better understand the consumers respond to the impact of food quality, price and others factors towards the overall level of satisfaction.

The findings suggest that restaurant managers should understand the needs of customer about how food quality can increase customer satisfaction. Food quality is the most important factor as a predictor of customer satisfaction in SME Bank Cafeteria. Restaurant managers are advised to put significant emphasis on the key attributes of food quality that can stimulate customer satisfaction in the restaurant industry context.

Hence, service provider of SME Bank Cafeteria should take note that students are willing to patron the cafeteria if

the food quality meets their expectation with a price which is affordable for students. Physical environment is not a determining factor for students to patronage. Hence, improving the quality of food with a reasonable price is a competitive edge for the service provider.

\section{REFERENCES}

[1] S.M. Loureiro SM, and F.J. González, "The importance of quality, satisfaction, trust, and image in relation to rural tourist loyalty", Journal of Travel \& Tourism Marketing. 2008 Oct 1;25(2), pp17-36.

[2] D. Tuzunkan, and A. Albayrak, "The importance of restaurant physical environment for Turkish customers," J Tourism Res Hospitality 5. 2016; pp 1:2.

[3] K. Ryu, and H. Han, "Influence of the quality of food, service, and physical environment on customer satisfaction and behavioral intention in quick-casual restaurants: Moderating role of perceived price," Journal of Hospitality \& Tourism Research. 2010 Aug; 34(3):310-29.

[4] SS. Andaleeb, and CC, Conway, "Customer satisfaction in the restaurant industry: an examination of the transaction-specific model," Journal of services marketing. 2006.

[5] W. G. Kim, C. Y. Ng, and Y. S. Kim, "Influence of institutional DINESERV on customer satisfaction, return intention, and word-of- mouth," International Journal of Hospitality Management. 2009 Mar 1;28(1):10-7.

[6] J. Hanaysha, "Testing the effects of food quality, price fairness, and physical environment on customer satisfaction in fast food restaurant industry," Journal of Asian Business Strategy, 2016 Feb;6(2):31-40

[7] K. S. Kumar, "Expectations and perceptions of passengers on service quality with reference to public transport undertakings.," IUP Journal of Operations Management, 2012 Aug 1;11(3):67.

[8] A. Yüksel, F. Yüksel, "Measurement of tourist satisfaction with restaurant services: A segment-based approach," Journal of vacation marketing, 2003 Jan;9(1):52-68.

[9] N. Barber, R. J. Goodman, and B. K. Goh, "Restaurant consumers repeat patronage: A service quality concern," International Journal of Hospitality Management, 2011 Jun 1;30(2):329-36.

[10] H. Aigbedo, and R. Parameswaran, " Importance-performance analysis for improving quality of campus food service," International Journal of Quality \& Reliability Management, 2004 Oct 1.

[11] J. M. Sulek, and R. L. Hensley, "The relative importance of food, atmosphere, and fairness of wait: The case of a full-service restaurant," Cornell Hotel and Restaurant Administration Quarterly, 2004 Aug; 45(3):235-47.

[12] Y. Liu, and S. S. Jang, "Perceptions of Chinese restaurants in the US: what affects customer satisfaction and behavioral intentions?" International Journal of Hospitality Management, 2009 Sep 1;28(3):338-48

[13] P. Benrit, and N. Trakulmaykee, "The Relationships among Food Quality, Service Quality, Physical Environment and Customers' Satisfaction in Thai Dining Restaurant in Malaysia," Journal of Management Sciences Suratthani Rajabhat University, 2016 Jun 30;3(1):41-62.

[14] A. A. Al-Tit, "The effect of service and food quality on customer satisfaction and hence customer retention.," Asian Social Science, 2015 Oct 1;11(23):129.

[15] E. W. Anderson, C. Fornell, and D. R. Lehmann, ”Customer satisfaction, market share, and profitability: Findings from 
Sweden,” Journal of Marketing, 1994 58(3) pp. 53-66.

[16] D. Karki, and A. Panthi, "A study on Nepalese Restaurants in Finland: How Food Quality, Price, Ambiance and Service Quality Effects Customer Satisfaction.," 2018

[17] C. Ranaweera, and A. Neely, "Some moderating effects on the service quality-customer retention link.," International journal of operations \& Production management, 2003 Feb 1.R. C. Lewis, and S. Shoemaker, "Price-sensitivity measurement: A tool for the hospitality industry," Cornell Hotel and Restaurant Administration Quarterly, 1997 Apr;38(2):44-54.

[18] S. Nadzirah, A. S. Karim, H. Ghazali, and M. Othman, "University foodservice: An overview of factors influencing the customers' dining choice," International Food Research Journal, 2013 May 1;20(3):1459.

[19] A. Garg, and J. Kumar, "Exploring customer satisfaction with university cafeteria food services. An empirical study of Temptation

restaurant at Taylor's University, Malaysia," European Journal of Tourism, Hospitality and Recreation, 2017 Dec 1;8(2):96-106.

[20] M. Amin, Z. Yahya, W. F. Ismayatim, S. Z. Nasharuddin, and E. Kassim, "Service quality dimension and customer satisfaction: An empirical study in the Malaysian hotel industry," Services Marketing Quarterly, 2013 Apr 1;34(2):115-25.

APPENDIX

TABLE 3. COEFFICIENT TABLE

\begin{tabular}{|c|c|c|c|c|c|c|}
\hline & \multirow[b]{2}{*}{ Model } & \multicolumn{2}{|c|}{$\begin{array}{l}\text { Unstandardized } \\
\text { Coefficients }\end{array}$} & \multirow{2}{*}{$\begin{array}{l}\text { Standardized } \\
\text { Coefficients } \\
\text { Beta }\end{array}$} & \multirow[b]{2}{*}{$\mathbf{t}$} & \multirow[b]{2}{*}{ Sig. } \\
\hline & & $B$ & Std. Error & & & \\
\hline & (Constant) & -.443 & .307 & & -1.444 & .152 \\
\hline & Food Quality & .700 & .095 & .592 & 7.351 & .000 \\
\hline & Price & 277 & .087 & 226 & 3.174 & .002 \\
\hline & Physical Environment & .153 & .102 & .115 & 1.501 & .137 \\
\hline
\end{tabular}

a. Dependent Variable: Customer Satisfaction 